DOI: $10.1515 /$ pcssr-2016-0022

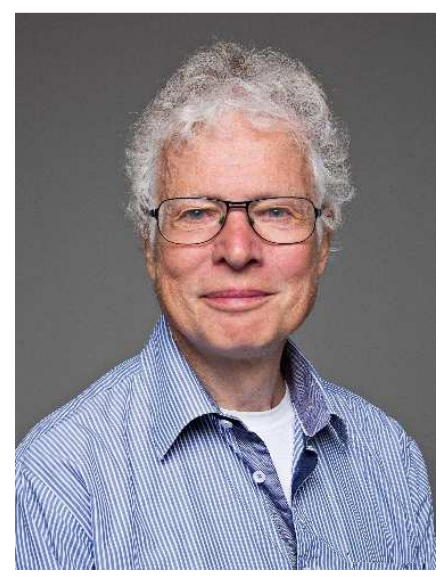

\title{
Body Culture, Play and Identity
}

\author{
Henning Eichberg ${ }^{1 \mathrm{~A}-\mathrm{E}}$, Jerzy Kosiewicz ${ }^{2 \mathrm{~A}, \mathrm{D}}$
}

${ }^{1}$ University of Southern Denmark, Denmark

${ }^{2}$ Josef Pilsudski University of Physical Educationin Warsaw

Authors' contribution:

A) conception and design of the study

B) acquisition of data

C) analysis and interpretation of data

D) manuscript preparation

E) obtaining funding

ABSTRACT

This is the second article of the cycle of portraits of the members of the Editorial Board and Editorial Advisory Board of the journal Physical Culture and Sport. Studies and Research, who are eminent social scientists researching the issue of sport. Among them, there are many world-class professors, rectors and deans of excellent universities, founders, presidents and secretaries-general of continental and international scientific societies and editors of high-scoring journals related to social sciences focusing on sport. The journal Physical Culture and Sport. Studies and Research started its activities in 2008 and gathered many readers, distinguished authors and outstanding reviewers. It is worth taking a moment to present the profiles of the individual editors, thanks to whom the journal keeps getting better and better. The journal is increasingly appreciated internationally particular among the scientists from the humanist and social areas of investigations. The rapidly increasing number of its readers and its surprisingly wide reception, indicated by the number of visits and downloads in English-speaking countries, including hundreds of universities (up to 791 were interested in the content of issue 62 of our magazine), research institutes and related libraries, as well as academics, researchers and students, should be celebrated. These data are derived only from one bibliographic data base (EBSCO). It must be noted that the journal is indexed in 43 bases.

KEYWORDS Education, academic achievements, scientific assumptions, publications

\section{Second portrait}

Once upon a time, there lived a king in Sweden, whose name was Adils. He was very fond of quick horses. One day, Adils rode around in a labyrinthine stone setting, the hall of the Dises, to sacrifice for those female deities. But speeding up, his horse stum-bled over one of the stones, and Adils tumbled down. He broke his skull so that his brain spread over the stone, and he died. He was buried in Uppsala. In a song, a skald praised Adils as a mighty king, who died by witchcraft. But maybe, it was his own speed that killed him, and Adils did not understand the pace and rhythm of the labyrinth? (After Snorri Sturlasson's Ynglingesaga, Norway, around 1230; retold in Eichberg: Questioning Play, 2016)

Henning Eichberg, professor emeritus, Dr. phil. habil., is a German-Danish historian, cultural sociologist, anthropologist, and philosopher. He teaches at the University of Southern Den-mark, Institute of Sports Science and Clinical Biomechanics, in the fields of body culture studies and the study of play. His 
research has mainly focused on the history and cultural sociology of body culture and sport, the phenomenology of play and games, and the philosophy of democracy, movement, and identity.

\section{Biography - from Silesia to Denmark}

Eichberg was born in 1942 in Schweidnitz/Silesia (Germany), today known as Swidnica in Poland. He grew up in Saxony in the German Democratic Republic from 1945-1950, and from 1950 on he lived in Hamburg. Studying history and literature in Hamburg, he started researching the history of technological and military culture, supervised by Alfred Timm. After archive studies in Stockholm, he received his PhD in history in 1970 at Ruhr University Bochum with a book on Swedish fortification in the seventeenth century in northern Germany and the early history of military engineering. In 1971, Eichberg joined the Institute of Sociology at the University of Stuttgart as an assistant professor, working in the Department of Historical Behavioral Studies under August Nitschke (https://en.wikipedia.org/wiki/Historical_behaviour_studies). In 1974-1975, he undertook social anthropological research in West Sumatra and lived among the rainforest Indians of Mentawai (Indonesia) in 1979.

In 1976, Eichberg received his postdoctoral degree in cultural sociology at the Faculty of Historical, Social, and Economic Sciences of Stuttgart University. For this habilitation, he presented two books: a historical study about the origin of modern sport and dance in the eighteenth and nineteenth centuries, and an anthropological study about rural development and social change in West Sumatra. From 1971 to 1982, he taught as an assistant professor at the Institute of Sociology, Stuttgart University, and from 1980 to 1982 he was also a substitute professor in sociology at the University of Osnabruck in the Vechta department.

In 1982, Eichberg was called to Denmark to build up the then non-existent humanistic study of sport. Until 1987, he held extraordinary professorships for the history and sociology of sport at the universities of Odense (Institute of Sport Science) and Copenhagen (Institute of Cultural Sociology). From 1987 to 2004, he worked as a researcher at Idratsforsk, the Institute of Sport Research at the Sports Academy of Gerlev, and in 1989-1991 as a senior scholar at the Danish State Institute of Physical Education (DHL) and the Centre of Sport Research at the University of Copenhagen.

Between 1983 and 1989, Eichberg was invited to Libya several times, where he had meetings with Muammar al-Gaddafi and his minister of sports, Ali Yehia al-Mansouri, and studied Libyan sport and Bedouin games. In 1987, together with French, German, and Danish researchers, he co-founded the Institut International d'Anthropologie Corporelle as a unit for experimental studies of body culture (https://fr.wikipedia.org/wiki/Anthropologie corporelle) and lectured in 1988-1989 as a visiting professor at the University of Rennes II. Beginning in 1991, he gave several lectures in Japan, where some of his publications were translated, and in 2002 he co-founded the Centre for the Study of Body Culture (Tsukuba/Japan) at the University of Tsukuba (http://www.taiiku.tsukuba.ac.jp/ sshimizu/research1.htm). He was also engaged in Poland with lectures and publications at universities in Gdansk, Poznan, Rzeszow, Legionowo, and Warsaw.

In 2004, Eichberg was called back to Odense, where he became an associate professor at the University of Southern Denmark and, in 2010, a professor at the Institute of Sport Science and Clinical Biomechanics. He worked at the Research Center of Sport, Health, and Civil Society (CISC), which succeeded the institute Idratsforsk. In 2005, he joined the proposal for an International Network for the Marxist Study of Sport.

Furthermore, Eichberg lectured at universities in Austria (Graz, Salzburg, Vienna), Finland (Jyväskylä), England (Keele), Germany (Tübingen, Berlin), Korea (Suwon), Norway (Oslo), Russia (St. Petersburg), Scotland (Stirling), Sweden (Lund), and Taiwan (Taipei).

According to his passport, Eichberg's nationality is German, but he identifies as a Silesian and calls Denmark his home country. He is married to Kirsten Kaya Roessler, professor of psychology at the University of Southern Denmark, and together they have two daughters. He also has three sons and five grandchildren from an earlier marriage. 
CV: http://www.sdu.dk/staff/heichberg.aspx

Wikipedia: https://en.wikipedia.org/wiki/Henning_Eichberg

Kürschners Gelehrtenlexikon, since 1980

Who is Who, since 2012

\section{Publications}

Eichberg has authored, co-authored, edited and co-edited more than 50 books and monographs, including:

- 1973: Der Weg des Sports in die industrielle Zivilisation [The way of sports into industrial civilization]. Baden-Baden: Nomos,

- 1976: Militär und Technik [Military and technology]. Düsseldorf: Schwann,

- 1977: Massenspiele. NS-Thingspiel, Arbeiterweihespiel und olympisches Zeremoniell [Mass plays. Nazi Thingsspiel, workers' plays, and Olympic ceremony] with M. Dultz, G. W. Gadberry, and G. Rühle. Stuttgart-Bad Cannstatt: Frommann-Holzboog,

- 1978: Leistung, Spannung, Geschwindigkeit [Achievement, suspense, speed]. Stuttgart: Klett Cotta.

- 1978: Nationale Identität [National identity]. Munich: Langen-Müller,

- 1981: Sozialverhalten und Regionalentwicklungsplanung (West Sumatra) [Social behavior and planning of regional development]. Berlin: Duncker \& Humblot,

- 1984: Die historische Relativität der Sachen [The historical relativity of things]. Münster: Lit,

- 1986: De grønne bølger [The green waves] with E. Jespersen. Gerlev: Bavnebanke,

- 1987: Liikuntaa harjoittavat ruumiit [Bodies in sportive movement]. Tampere: Vastapaino,

- 1988: Leistungsräume. Sport als Umweltproblem [Spaces of achievement. Sport as an environmental problem]. Münster: Lit,

- 1989: Festung, Zentralmacht und Sozialgeometrie [Fortification, central power, and social geometry]. Cologne: Böhlau,

- 1994: Idrattens tredje vej [The third way of Danish sports] with C. Bøje. Aarhus: Klim,

- 1997: På kryds og tvars i kulturpolitikken [Criss-cross in cultural policy] with S. Abildå, et al. (Eds.). Aarhus: Socialist People's Party,

- 1997: 身体文化のイマジネーション： デンマークにおける「身体の知」[Imaginations of body culture]. Tokyo: Shinhyoron,

- 1998: Body Cultures. London: Routledge,

- 2004: The People of Democracy. Aarhus: Klim,

- 2007: Sport for All as a Form of Education with J. Kosiewicz and K. Obodyńsky (Eds.). Rzeszow: University of Rzeszow,

- 2010: Bodily Democracy. Towards a Philosophy of Sport for All. London: Routledge,

- 2011: Minderheit und Mehrheit [Minority and majority]. Münster: Lit,

- 2012: Idratspolitik i komparativ belysning - national og international [Sports policy in comparative perspective - national and international]. Odense: Syddansk Universitetsforlag,

- 2015: 身體文化研究 由下而上的人類運動現象學。莊珮琪、李明宗譯。新北市：臺灣身體文化 學會、康德出版社。[The study of body culture - Towards a bottom-up phenomenology of human movement]. Taipei: Taiwan Body Culture Society,

- 2016: Questioning Play. London: Routledge.

He has also contributed to several encyclopedias and handbooks:

- Geschichte und Militärgeschichte [History and military history]. Frankfurt/M., 1974,

- Geschichte der Leibesübungen [History of physical exercises]. Berlin, 1980 and 1989,

- Lexikon des Sozialismus [Encyclopedia of socialism]. Cologne, 1986,

- Handbuch der deutschen Bildungsgeschichte [Handbook of German educational history]. Münster, 1989 , 
- Encyclopedia of World Sport. Santa Barbara, 1996,

- International Encyclopedia of Women and Sports. New York, 2001,

- Handbuch Populäre Kultur [Handbook of popular culture]. Stuttgart, 2003,

- Berkshire Encyclopedia of World Sport. Great Barrington/Mass., 2005,

- Krieg in der Europäischen Neuzeit [War in European modernity]. Vienna, 2010,

- $\quad$ Routledge Companion to Sports History. London, 2010.

Eichberg has published chapters in more than 240 books and many articles in scholarly periodicals in seventeen languages.

He was a member of the editorial boards of national and international journals:

- Stadion, International Journal of the History of Sport, Cologne and Leiden, from 1975,

- Tidsskrift for Idrcet [Journal of sport], Denmark, 1986-1989,

- International Review for the Sociology of Sport, 1992-1996,

- International Journal of Eastern Sports \& Physical Education, Suwon/Korea, 2004-2010,

- Ido - Ruch dla Kultury/Movement for Culture, University of Rzeszow/Poland, from 2004,

- Journal of Sport History, North American Society for Sport History, from 2007,

- Physical Culture and Sport. Studies and Research, Jozef Pilsudski University of Physical Education in Warsaw, from 2007,

- Scandinavian Sport Studies Forum, Malmö/Sweden, from 2010,

- EAST - East Asian Sport Thoughts, Taiwan, from 2013.

\section{Awards}

- 1974 Award of the Friends of the University of Stuttgart,

- 1974 Award in the Carl Diem competition of the German Sport Federation (DSB),

- 1981 Gerlev Award of Gerlev Sports Academy,

- 1989 Order of the Socialist Libyan People's Jamahiriya,

- 2015 Play Award at Gerlev Sports Academy.

\section{Research - findings and controversies}

Eichberg's scholarly findings have been with met international recognition, but they have also provoked controversies.

\section{Historical relativity and the sociology of surprise}

As a historian of technology, Eichberg has described the geometrical bastion fortification of the seventeenth century as part of a societal pattern - social geometry. In contemporary body culture, this manifested in geometrical exercises such as court dance, horse ballet, and court ballgames. Social geometry changed with the dawn of industrial society, when blitzkrieg made the world of regular fortifications disappear. Synchronically, the geometrical exercises were marginalized by time-dynamic waltz and sport. This showed the historical relativity of technological rationality. Social geometry, however, became a disputed concept.

While history is often understood as tradition, it was here reinterpreted as change. Historical thinking is thus not defined by the study of past times as such, but it contributes to the understanding of the future. Eichberg analyzed the history of movement culture alongside with what Elias called the process of civilization and what Foucault characterized as the configurational change of the order of things in sciences. Historical change does not proceed in a linear process, but by discontinuities and revolutions. This makes up a sociology of surprise - and a history of disappearance. Will sport disappear, just as the medieval castles and the Baroque fortifications and horse ballets became memories of the past?

In this perspective, history is not just one particular sector among other disciplines of knowledge. But there is no philosophical and sociological understanding of phenomena without recognition of their historical relativity. All is change. And history moves by jumps, by revolutions. 
For the relativity of knowledge, the sociology of surprise, and for playful questioning, Eichberg referred to Situationism and the writings of Henri Lefebvre, Guy Debord, and Asger Jorn (Dressen, 1991, pp. 92-105).

\section{National identity - otherness and recognition}

Eichberg's studies of play and sport had a special focus on ethnic activities, on cultural minorities and their identities, from Minangkabau/Indonesia to Scotland, and from Greenland to Sukuma/Tanzania. It was under the heading of identity that the first controversies about his writings were instigated. With the displacement and ethnic cleansing of Silesia in 1945 being part of his biographical background, Eichberg engaged as a student among German nationalists and became - under the influence of French nationalists - a spokesperson of the German New Right (Glotz, 1989, pp. 137-41; Maass, 2014, pp. 75-84). He wrote for national revolutionary publications, which regarded the German question as being open but were critical of the conservative and Nazi "Old Right". He predicted the breakdown of the Soviet Union and the Communist East German state because of national aspirations. During the 1970s, Eichberg's writings about folk and the national question were also published in periodicals of the intellectual left wing, such as Ästhetik und Kommunikation, the ex-Maoist Befreiung, and the anarchist Unter dem Pflaster liegt der Strand.

In the early 1970s, Eichberg traveled to Ireland, where he became fascinated by folk music and rebel songs and had encounters with leaders of the Republican movement, both the "Official" and the "Provisional" Sinn Fein. On this basis, he held his inaugural lecture about nationalism and revolution in Ireland, which entered into his book Nationale Identität (1978). This volume shifted the perspective of the national question from national interests, such as territory, borders, and economical interests, to identity, and was regarded as being crucial to the breakthrough of the German concept of "national identity". From the side of liberal individualism, however, it was criticized as an invention of fascist and left-wing Marxist intellectuals creating disorder in social theory.

During the 1980s, Eichberg pointed towards the contradiction between identity and alienation as the main field of cultural sociology, understanding identity not as a biological organism, but as cultural and social, in line with the psychoanalytical approach of Erik H. Erikson and connected with the concept of habitus developed by Max Weber and Pierre Bourdieu. In the framework of play research, Eichberg discussed play alongside identity and in opposition to alienation.

In relation to the question of identity and as part of a critical debate against neo-colonial Western cultural export, Eichberg launched the concept of ethnopluralism in 1973. In opposition to ethnocentrism, the recognition of ethnoplurality represented a perspective of difference and non-colonial relations. The concept of ethnopluralism was, however, also later distorted by right-wing nationalists, with connotations of ethnic apartheid.

In the late 1970s, Eichberg became more and more recognized as a left-wing author. He joined the antiauthoritarian left wing and engaged in the building of the German green-alternative movement. Critics suspected that Eichberg's "dangerous thinking" would "infiltrate" intellectual culture (Teichmann, 1991; Heni 2007), while other scholars opposed this interpretation (Brownell, 1998; Seitenbecher, 2013). Because of the "intellectual subversion" of his writings, Eichberg was set under observation of the secret services of both West Germany (Verfassungsschutz) and East Germany (Staatssicherheit).

In Denmark, however, Eichberg's critical studies about folk and national identity found a positive response, as they corresponded to the Danish traditions of democratic left-wing nationalism represented by the Danish nation-builder N.F.S. Grundtvig (Hall, 2015). Eichberg joined this intellectual community after his emigration in 1982 and published in the milieu of the Grundtvigian Folk Academies. He obtained a Festschrift under the title Folk - about a basic concept in democracy and culture (Møller, 2004). In 1988-1996, he held political-philosophical study workshops at socialist summer camps, and in the early 1990s, he was affiliated with the Danish Socialist People's Party (SF). After being appointed a member of the party's cultural commission, he edited a book and wrote several papers about cultural policy from the socialist perspective. 
In the field of sport, games, and body culture, Eichberg's attention to ethnic and national identity induced studies under anti-colonial and post-colonial perspectives, and in particular about games and sport in West Sumatra, Mentawai/Indonesia, Libya, Tanzania, and Greenland. Sport and games among ethnic minorities and in post-colonial cultures are related to and contribute to folk awareness and self-determination. After 19891992, the national question, which had been deemed dead or outdated by liberal Western thinkers, obtained new actuality, especially in the Eastern Hemisphere, and Eichberg edited a translation of a Russian study about "ethnosport" among the peoples of the East (Kylasov, 2015). The national question obtained new significance as an anti-colonial question: Who are we?

The analysis of identity revealed, however, important inner differences. Through comparative studies, Eichberg differentiated between the identity of competition as in achievement sport, the identity of discipline as in gymnastics, and the folk identity of encounter as in traditional games and festivities. Identities can be placed in hierarchical order (sport), or demonstrated through disciplinary equality (gymnastics), or imply the recognition of otherness (Pavlin, 2008, pp. 222-239).

\section{Body culture}

On the methodological and philosophical level, Eichberg launched the concept of body culture, which in a deeper sense casts light on the place of sport in culture and society. Body culture includes sport alongside with dance, play and games, meditative activities, outdoor activities, and rituals. Eichberg placed the concept of body culture side by side with material culture (artifacts and technology) and intellectual culture (arts and values). Philosophically leaning towards Karl Marx, Eichberg grounded the concept of body culture on a materialist understanding of bodily practice as the basis beneath the superstructure of ideologies and institutions.

The concept of body culture - originally Danish kropskultur and German Körperkultur - was broadly received in the international community of research (Pope, \& Nauright, 2010; and https://en.wikipedia.org/wiki/Body_culture_studies). For Asian studies, the American anthropologist Susan Brownell used it especially in her anthropological study of Chinese sport, while the Japan-based Centre for the Study of Body Culture (Tsukuba) and the Taiwan Body Culture Society (Taipei) were established for the study of regional body cultures.

The concept of body culture was also related to anthropologie corporelle (bodily anthropology). This was an approach for developing anthropology through the bodily experiences of research communities in living settings.

On the level of phenomenological analysis, the study of body culture was supplemented by the method of configurational analysis. Eichberg used configurational analysis to describe the patterns of space, time, energy, interpersonal relations, and production in human movement (https://en.wikipedia.org/wiki/Configurational_analysis).

Although he was critical of the established state-Marxist theories of sport, Eichberg entered into an exchange with the Marxist sport historian Andrzej Wohl from Poland, who spent some time at Gerlev. In the midst of the breakdown of the GDR, the Marxist sport philosopher Walter Sieger recommended Eichberg's studies of sport and body culture for the renewal of critical theory.

\section{The modernity of sport}

Through historical studies, the analysis of body cultural change revealed the specific modernity of sport. In line with the German sociologist Norbert Elias and the American historian Allen Guttmann, and through his personal connection with both of them, Eichberg analyzed how sport arose during the eighteenth century as a new practice characterized by the objectification of movements and games - c-g-s sport (centimeters, grams, seconds). In this type of sport, the focus was on results, using the measurement and quantification of records 
and targeted training. This contrasted with the former culture of festivity and carnival that had been the context of traditional play and games among the classes of the rural folk as well as the townspeople and the aristocracy. The specifically modern pattern of sport questioned the widespread assumption that there was "sport" in ancient Greece, or even - as is documented in cave drawings - in Stone Age society. In contrast to this sport ideology, sport was revealed as a part of modern industrial behavior with its focus on achievement, suspense, and acceleration. In some way, the modern practice of sport even prefigured industrial productivity. Thus, sport was a historically relative phenomenon, neither a universal nor an eternal phenomenon of human existence.

The so-called Eichberg-Mandel-Guttmann theory about the modernity of sport provoked sharp criticism among some sport historians. Conservative scholars tried to demonstrate that records and results had already been measured in earlier historical periods and in non-Western cultures, and thus were a universal phenomenon. This resulted in disputes about "sport" phenomena in Renaissance Europe, among Pacific folk cultures, and in pre-modern Japan (Carter, \& Krüger, 1990).

By underlining the specific modernity of sport, sport became an object of a cultural theory of relativity. The Finnish sociologist Esa Sironen placed Eichberg's contribution to the societal relativity of body culture in the triangle between the sociology of Norbert Elias, the philosophy of Michel Foucault, and the critical theory of the Frankfurt School.

\section{Sports critique - sport as a cultural struggle}

By understanding sport as being culturally and historically relative, a critical perspective opened towards sport. If sport was not seen as a universal phenomenon or a normative "function", but rather as one body culture alongside other body cultures in the world, then sport could be seen as a matter of "cultural struggle", a "struggle concerning the body", or one of many other alternatives.

From an intercultural perspective, the sports critique implied a critical post-colonial history of the Olympic model. Sport as a specific Western project had undertones of racism and was connected with capitalist hegemony (Bale, \& Christensen, 2004, pp. 65-80; Brownell, 1904, pp. 343-382). If sport was not just one general phenomenon worldwide, then there was an implied recognition of cultural difference and of the otherness of indigenous games. Scholars from mainstream sport functionalism attacked this as "Third World romanticism".

Sports critique also provided inspiration for analyzing the internal problems of elite sport, such as doping, corruption, match fixing, and money washing, as expressions of deeper patterns and more fundamental problems than just individual criminality, even deeper than the results of commercial hegemony and capitalist interests. This critical perspective encouraged investigative journalism, which, on the international level, was organized around the Danish-based journalist conference Play the Game, to which Eichberg contributed from its very beginning (Møller \&\& Andersen, 1998, pp. 167-174).

Another aspect of sport critique was of an environmental character: the critique of the functionalism of sport facilities. Through the study of the container architecture of sport, Eichberg contributed to a critical ecology of sport, which was met with the more general green environmentalism of the 1980s. On the constructive side, these studies resulted in establishing the Danish Foundation of Sport and Culture Facilities in 1993. This foundation was sponsored by the Danish Ministry of Culture to promote and advise alternative and culturally advanced sport facilities.

The sport-critical school of Gerlev provoked sharp inner-Danish debates, especially because of its intervention in national sport policy. Within the framework of a broader evaluation of Danish cultural policy, the Social Democratic minister of culture ordered a report about Danish sport policy in 1994, which was written by Eichberg and other Gerlev scholars. Although the president of the Danish Sport Federation refused this book as a product of the "culture-radical spinach patch of Gerlev", it became a sort of standard reference. In 2003, however, the new Conservative minister of culture ceded to the Olympic sport federation press and 
liquidated financial support for the Gerlev Idratsforsk.

\section{Traditional games and green waves}

The recognition of difference and otherness in body culture brought about new attention for movement practices outside sport, especially old folk games and outdoor activities. Among these, the traditional games became objects of research and political re-evaluation. Eichberg contributed with studies of indigenous play cultures in Indonesia, Libya, Tanzania, Rwanda, Greenland, Bretagne, and Scotland. Publications in this field appeared in several volumes about traditional games and in the reviews Lo joa' e les omo (Valley d'Aosta, Italy) and International Journal of Eastern Sports and Physical Education (Suwon, Korea). This research also entered into international networks and exchanges such as the European Traditional Sport and Games Association (ETSGA) and boosted awareness for traditional games at the UNESCO level. The Russian concept of "ethnosport" (Kylasov, 2015) made connections between movement culture and ethnic identity visible too, creating a new internationalism of body culture.

Eichberg's studies of indigenous play, folk games, and ethnic sport also shed light on the connection between play and festivity, which contrasted with the disciplinary production of sport results. Sport history went from festivity to production, while also revealing subversive elements of folk festivity inside modern sport. Furthermore, the carnival elements of play showed - in prolongation of the classic study of Mikhail Bakhtin - the importance of the culture of laughter for human play and games (Chamayou, \& Duncan, 2010, pp. 305-326).

An additional field of movement culture outside competitive sport includes outdoor activities, such as wandering, scouting, and Nordic friluftsliv. Eichberg showed in his history of Danish friluftsliv that outdoor activities - getting "back to nature" - did not develop in a linear way, but rather in waves, corresponding to the synchronous waves of revolutionary unrest in society. Folk practice oscillated between green revolutions and the colonization of nature. These discontinuities could be understood trialectically: through contradictions between nature as a whole (as in "natural sciences"), nature as the other "out there" (as in getting "back to nature"), and nature inside (as in the "fractal geometry" of nature).

The dominance of elite sport is furthermore challenged by "sport for all". Eichberg proposed a philosophy for this field and contributed to the start of the International Sport and Culture Association (ISCA) in 1995.

\section{Bodily democracy}

From Eichberg's perspective, sport was not only a distinct sector of cultural activity, it also held broader significance for social life. Body culture and sport are especially significant for democracy. If democracy as a practical life form is more than representation on the institutional level, then it reveals dimensions of bodily democracy. Eichberg developed the concept of bodily democracy to describe cultural and social selfdetermination and recognition of otherness, which was related to common bottom-up activities in civil society, folk games, and sport for all.

Under the aspect of bodily self-determination, the study of sport contributed to a broader and more differentiated understanding of "folk" and "the people". In line with Johann Gottfried Herder, N.F.S. Grundtvig, and Martin Buber, and based on the history of folk games, Eichberg differentiated between the cultural folk of ethnos, the political folk of demos, and the social folk. However, these three dimensions of collective life are connected. They share the concepts of self-understanding, communication, and selfdetermination from the bottom-up.

Additional aspects of bodily democracy came forward through the comparative and historical studies of sport policies. Here, Eichberg's main focus was on Denmark, Norway, and Scotland. Through their decoupling, Scottish soccer and rugby preceded the political devolution of the nation. 
Bodily democracy obtained a special place in Eichberg's studies of play and alienation. Since the end of the eighteenth century, sensitive intellectuals have again and again expressed the experience and climate of something "alien" in their life. Finding the point of opposition against alienation became a significant motivation for Romantic literature, Karl Marx, and later for radical left-wing intellectuals: Could opposition to alienation be found in art, nature, religion, revolution, socialism? Eichberg proposed to see play as a practical opposition to alienation: In play, the human being does not feel alienated. The here-and-now of play contrasts with acceleration and stress, which characterize modern alienated life. And yet, play can be subjected to alienating influences, too, as is the case with media sport, war games, ludomania, and shopping.

\section{Playing, asking, and differential phenomenology}

In his later works, Eichberg turned to studies in the culture and philosophy of play. If play is understood as a way of questioning the world, questioning appears as a way of playing. Both play and questioning are expressions of playful curiosity - moving in curved lines, oscillating to and fro, and combining quest and surprise, expectation, fear, and laughter. The practice of both play and questioning are deeply rooted in the human being as homo poeticus. Without questioning, there is no knowledge; without play, is there knowledge? The human abilities to play and to ask are connected with the narrative practice and the dialogical sociality of the poetical human being.

This contributed to phenomenology more generally. Phenomenology appears as a humanistic alternative to physicalist positivism, but there is not just one phenomenology. Eichberg underlined the difference between phenomenology as a method and as an ontological philosophy, thereby stirring up some controversy.

On one hand, phenomenology originated as a method of critical and differential thinking, unfolding with Johann Wolfgang von Goethe's phenomenology of colors. Eichberg also referred to Martin Buber's (1992) philosophy of Thou and the dialogue, Gaston Bachelard's psychoanalysis of fire, Maurice Merleau-Ponty's phenomenology of bodily perception, Max Horkheimer and Theodor W. Adorno's dialectics of enlightenment, Erik Erikson's psychoanalysis of identity, Roger Caillois' epistemology of play and game, Lin Yutang's phenomenology of playful curiosity, Michel Foucault's phenomenology of discipline, and Peter Sloterdijk's phenomenology of social spheres.

On the other hand, beginning in the early twentieth century, existential ontology adopted the name of phenomenology and applied it to a speculative philosophy about "Being" (Martin Heidegger). Eichberg criticized this school for its lack of historical depth and cultural diversity. Instead of going back to the phenomena, the current phenomenology of sport argued for going back to the phenomenologists - to Husserl, Heidegger, etc. Phenomenology thus fell into the trap of academic authoritarianism and appeared as a narrow school of self-references. Eichberg's critique provoked a controversy with the phenomenologists Irena Mantínková and Jim Parry (2013).

\section{Critical theory}

Since Goethe, phenomenology had been connected with a fundamental critique of positivist reductionism. Around 1970, Eichberg himself became fascinated with neo-positivism and especially with the writings of the young Ludwig Wittgenstein; this is why his later critique also had the character of self-critique.

Positivist concepts and norms of academic study are typically derived from physics or mathematics, i.e., from studies in non-human matter. Their fascination with the "clear" and "evident" results from this, as do their limitations. The transfer of physicalist concepts to the study of human life and its complexity becomes a problem.

The "definition" that is demanded by positivist research presupposes the existence of limits (Latin fines), which do not exist in the world of human life because of historical change and cultural diversity. Human practice cannot be defined by little boxes, but must be described as phenomena. 
"Function" is derived from mathematics and cannot be transferred to human life, in spite of the attempts of sociological functionalism. Here, one can better talk about relations.

"Factors" are used in statistical analysis and associate causal explanation. In humanist studies, they can be replaced by "connections".

"Explanation" proceeds lineally from reason to effect. This linear causality calls for alternatives. For the cases of play and games, as well as for the human experience of nature, Eichberg proposed fractal logic, which was discovered by Benoit Mandelbrot. In contrast to explanation is understanding, as a reconstruction of complex connections and relations.

Discourse about the "individual" isolates an undividable monad, while Friedrich Nietzsche pointed to the human existence as "dividual". Instead of "individual", one should speak about the human being and its identity.

Positivism furthermore implies an implicit normativity, confronting the functional with the dysfunctional, useful thinking with useless speculation, and normality with the abnormal. This normative approach may hinder knowledge when studying human practice, as in the case of Olympic sport idealism. Play research is likewise often disturbed by pedagogical idealism, which Eichberg countered with studies of "dark play" - war as a bloody game.

Another critical point of positivist scientism is the absence of thinking contradictions. Contradictions are part of discovery and building knowledge, as in dialectical thinking. However, dialectical thinking has a tendency to lead to dualistic reduction, which is why Eichberg proposed trialectical thinking as a corrective. The third is able to enlighten contradictions of A versus B. Trialectical analysis has especially been applied to the inner differentiation of sport and games: sport achievement versus gymnastic discipline versus folk play. It may also have meaning for the role play of gender: male versus female versus the third.

Furthermore, Eichberg's study of play problematized positivist reductionism by pointing to the human practice of questioning: Truth is not generated through correct answers as such, but rather through their interplay with questions.

"How can we know?" is related to the question "How do we play?" Human knowledge is not just a copy of reality, but is created poetically, driven by questions and playful curiosity. An important part of this process is the play of language. On the linguistic level, Eichberg contributed with studies of "the body" as the body we have versus the body we are, which in German is expressed by Körper versus Leib. A further dialectical relation is the linguistic differentiation between "play" and "game" - in Danish, leg and spil - with "display" as a third.

Play and knowledge also mirror each other through the dialectic between division and community. Ballgames fascinate by dividing a given social whole into teams, which by their playful opposition create enthusiasm and identification - the festive community. In a similar way, dialectical thinking divides the whole of the world into contradictions, thereby creating knowledge. Dividing and uniting and dividing again... The human being of play is, like the human being of knowledge, a homo poeticus.

It would, however, be insufficient to understand the critique of positivism and reductionism in human studies as a purely intellectual matter. The dominance of physicalism and functionalism, of factor-thinking and reductionism, has its societal background in the management logics of power. Using the top-down rationality of management thinking, such as in New Public Management, human beings are reduced to numbers. Everything revolves around growth, efficiency, and leadership, while history, culture, and conflict disappear. The cultural struggle between system-functionalism, efficiency measurement, and data-reductionism on one hand and the narrative and historical understanding of phenomena on the other seems to be part of a new class struggle. The epistemology of sport, play, and games thus has a deeper political meaning, with culture arising as an alternative to measurable wealth.

\section{Deep play - the religious dimension of movement}

The connection between body culture, play, and identity reveals a deeper dimension: the dimension of 
the sacred. If religion is not understood as belief, i.e., as a matter of thinking, and is rather understood as the cultural and social doing of human beings, it appears as a world of ritual practice and festivity, of joint singing and poetical community.

In this context, Eichberg studied religiosities such as the proletarian freethinker movement, mass plays of the socialist workers' movement and the Nazi Thingspiel, Catholic asceticism, folk myths such as the Danish nisse dwarfs and the Silesian mountain spirit Rübezahl (Czech Krakonoš, Polish Liczyrzepa), the labyrinth as a dancing ritual, the medieval ecstatic dances of St. John, the Inuit shaman drum dance, skiing in the construction of the Norwegian identity, and yoga as part of the Hindu identity. Through play and bodily movement, people approach the holiness of life. From this perspective, religion appears as part of the deep play of the poetical human being.

The player - homo ludens - is thus not only a specialist who practices play and games in a delimited sector of leisure. The playing human being acts as homo poeticus, questioning the world and creating a cultural and social universe through play and games. Deep play and deep curiosity are connected by trying and failing and trying again, asking and answering and asking again, dividing and uniting and dividing again.

Thus, the question of anthropology is raised anew: Is the human being characterized by work during the day and rest at night, by production and reproduction? Or is the human being dreaming at night, and playing and questioning during the day?

The one-way labyrinth is known from Stone Age rock carvings and Old Nordic stone settings, from the Mediterranean, India, and certain Native American cultures. It was used as dance choreography, with matriarchal connotations, but also for races and riding, ball games and fighting matches. During the early nineteenth century, labyrinths were re-established on German and Russian gymnastic grounds. And yet, the labyrinth keeps a mystery: What is the deeper meaning of moving in the labyrinth? - The pattern of the labyrinth is related to the question mark: quest and striving to and fro, combining the point and the curved line, uniting regularity and irregularity. The starting point is the point of finish, and vice versa. Gymnasts called the labyrinth a Wonder Circle, and indeed, the labyrinth is a space of wondering, of expectation and surprise, fear and laughter, personal quest and togetherness. Like the question mark, it contrasts the rationality of the straight line. The labyrinth depicts the connection between playful movement and question, between human bodily play and Figure 1. One way-labyrinth the human quest of knowledge (Questioning Play, 2016). Source: http://www.labyrinthos.net

\section{REFERENCES}

Bale, J., \& Christensen, M.K. (Eds.) (2004). Post-Olympism? Oxford: Berg.

Brownell, S. (1998). Thinking dangerously. The person and his ideas. In H. Eichberg (Ed.), Body Cultures (pp. 22-24). London: Routledge.

Brownell, S. (Ed.) (2008). The 1904 Anthropology Days and Olympic Games: Sport, Race and American Imperialism. Lincoln: University of Nebraska Press.

Buber, M. (1992). Jeg og du /I and thou/. Preface by H. Eichberg. Copenhagen: Reitzel.

Carter, J.M., \& Krüger, A. (Eds.) (1990). Ritual and Record. Sports Records and Quantification in Pre-Modern Societies. New York: Greenwood.

Chamayou, A., \& Duncan, A.B. (Eds.) (2010). Le rire européen. European Laughter. Perpignan: Presses Universitaires de Perpignan.

Dressen, W., Kunzelmann, D., \& Siepmann, E. (Eds.) (1991). Nilpferd des höllischen Urwalds. Situationisten, Gruppe SPUR, Kommune I/Hippo of the infernal jungle. Situationists, Group SPUR, Commune I/. Berlin: Werkbund. 
Glotz, P. (1989). Die deutsche Rechte /The German right wing/. Stuttgart: DVA.

Hall, J.A., Korsgaard, O., \& Pedersen O.K. (Eds.) (2015). Building the Nation. N.F.S. Grundtvig and Danish National Identity. Montreal: McGill-Queens University Press.

Heni, C. (2007). Salonfähigkeit der Neuen Rechten. Henning Eichberg als Exempel /Acceptance of the New Right. Henning Eichberg as example/. Marburg: Tectum.

Kylasov, A. (2015). Ethnosport - The End of Decline. Preface by H. Eichberg. Münster: Lit.

Maass, S. (2014). Die Geschichte der Neuen Rechten in der Bundesrepublik Deutschland/The history of the New Right in the Federal Republic of Germany/. Kiel: Regin.

Martínková, I., \& Parry, J. (2013). Eichberg's “phenomenology” of sport: A phenomenal confusion. Sport, Ethics and Philosophy, 7, 331-41.

Møller, J., \& Andersen, J.S. (Eds.) (1998). Society's Watchdog - or Showbiz’ Pet? Inspiration for a Better Sports Journalism. Vejle: DGI.

Møller, J. (Ed.) (2004). Folk - om et grundbegreb i demokrati og kultur /Folk - about a basic concept in democracy and culture/. Århus: Klim.

Pavlin, T. (Ed.) (2008). Šport, narod, nacionalizem. Sport, Nation, Nationalism. Ljubljana: Fakulteta za šport.

Pope, S.W., \& Nauright, J. (Eds.) (2010). Routledge Companion to Sports History. London: Routledge.

Seitenbecher, M. (2013). "Wenn die Nationalisten vom revolutionären Mai sprechen, sagen sie: ,wir“". Henning Eichbergs Weg von der Rechten zur Linken über die 68er-Bewegung /"When the nationalists talk about the revolutionary May, they say 'we'". Henning Eichberg's way from the Right to the Left through the 68 movement/. Extremismus \& Demokratie, 25, 79-93.

Teichmann, F. (1991). Henning Eichberg - nationalrevolutionäre Perspektiven in der Sportwissenschaft /Henning Eichberg - national revolutionary perspectives in sport science/. Frankfurt/M.: Peter Lang.

$\begin{array}{ll}\text { AUTHOR'S ADDRESS: } & \text { Henning Eichberg } \\ & \text { University of Southern Denmark } \\ & \text { Campusvej 55, 5230 Odense M } \\ & \text { Denmark } \\ & \text { E-mail: heichberg@health.sdu.dk }\end{array}$

Received: 5 September 2016; Accepted: 14 November 2016 